\title{
Co-Application of Farmyard Manure and Gypsum Improves Yield and Quality of Peanut (Arachis hypogaea) under Rainfed Conditions
}

\author{
Rizwan Latif $^{1 \dagger}$, Muhammad Junaid Afzal ${ }^{2 \dagger}$, Muhammad Imran Khan ${ }^{2 *}$, Muhammad Shaharyar Khan ${ }^{2}$, Muhammad \\ Asaad Bashir ${ }^{3}$, Saddam Hussain ${ }^{4}$ and Muhammad Ehsan ${ }^{1}$ \\ ${ }^{1}$ Soil and Water Testing Laboratory Chakwal, Pakistan \\ ${ }^{2}$ Institute of Soil and Environmental Sciences, University of Agriculture, Faisalabad 38040, Pakistan \\ ${ }^{3}$ Department of Soil Science, Faculty of Agriculture and Environment, The Islamia University of Bahawalpur, Pakistan \\ ${ }^{4}$ Department of Agronomy, University of Agriculture, Faisalabad, Pakistan \\ *Correspondence author: khanimran1173@yahoo.com \\ ${ }^{\dagger}$ Contributed equally to this work and are co-first authors \\ Received 18 January 2021; Accepted 04 May 2021; Published 10 July 2021
}

\begin{abstract}
Peanut (Arachis hypogaea L.) is the common cash crop of the rainfed areas. Appropriate management practices are very important to get better yield of peanut in sandy loam soil. A field study was carried out during the growing seasons of 2018 and 2019 to evaluate the effect of poultry manure (PM) $\left(37.1 \mathrm{t} \mathrm{ha}^{-1}\right)$, farmyard manure (FYM) $\left(49.4 \mathrm{t} \mathrm{ha}{ }^{-1}\right)$, gypsum $(\mathrm{GYP})$ $\left(2.5 \mathrm{t} \mathrm{ha}^{-1}\right)$, liquid humic acid (HA) $\left(49.4 \mathrm{~L} \mathrm{ha}^{-1}\right)$ and co-application of GYP $\left(1.2 \mathrm{t} \mathrm{ha}^{-1}\right)$ and FYM $\left(24.7 \mathrm{tha} \mathrm{t}^{-1}\right)$ on peanut yield, quality and soil physical properties. Application of FYM, PM, HA and GYP (alone or in combination) significantly improved peanut yield, quality and soil physical properties. The combined application of GYP and FYM proved most effective $(P \leq$ 0.05) in improving the peanut yield (no. of pods per plant, 100 seed weight etc), quality (crude protein and oil content) and soil physical properties (moisture percentage, infiltration rate and bulk density). The combined application of GYP and FYM increased the pods yield by 67 and 65\% during 2018 and 2019, respectively than control. Crude proteins (21\%) and oil contents $(9.0 \%)$ were also substantially increased in the combined application. Moreover, the combined application of GYP and FYM significantly retained the soil moisture and reduced bulk density of soil. Present findings suggest that integrated use of FYM and GYP under field conditions could improve the crop productivity, crude protein, oil contents, moisture percentage, and reduce the bulk density of soil thus improving overall soil health. (C) 2021 Friends Science Publishers
\end{abstract}

Key words: Farm yard manure; Poultry manure; Gypsum; Humic acid; Peanut; Soil health

\section{Introduction}

Peanut (Arachis hypogaea L.) also known as the "king of oilseed" belongs to the family fabaceae as one of the world's largest legume crop, ranks $2^{\text {nd }}$ after soybean (Glycine max L.) (Shad et al. 2009) and can be cultivated across diverse climatic conditions (Kiniry et al. 2005). It is ranked $13^{\text {th }}$ among the food crops and $4^{\text {th }}$ among oilseed crop, and its haulm is used as animal feed (El-Akhal et al. 2013; Meena et al. 2016).

The low agricultural productivity of peanut is attributed to various factors including low quality of seed, imbalanced fertilizer use, drought, unavailability of irrigation water, seasonal variation in rainfall patterns, and infertile soils due to low organic matter (Ashfaq et al. 2003; Hussainy and Arivukodi 2019). As compared to other field crops, the cultivation of oil seed crops such as soybean, sunflower (Helianthus annuus L.), and peanut have not received much attention (Kephe et al. 2020). The oil contents of peanuts are higher than soybean, hence considering peanuts oil quality, its cultivation could be considered as an alternative (Wang et al. 2012). Increase in area under cultivation and yield of peanut is possible through quality seed, proper soil management practices and efficient nutrient management such as integrated use of organic and inorganic nutrients (Mahrous et al. 2015).

Among the amendments, organic manures improve soil fertility, water-holding capacity, and overall biomass of plant growth promoting microbes (Esmaeilian et al. 2012). Moreover, organic manures are being preferred over inorganic fertilizers in improving soil physical properties (Busscher et al. 2010). Peanut as a potential oilseed crop requires an adequate amount of nutrients especially phosphorus (P) and potassium (K). Proper nutrient management is the key factor among the best agronomic practices, supporting sustainable crop production for longer run without disturbing soil fertility and health (Sarkar et al. 2017; Kumar et al. 2018). There is a direct relation between

To cite this paper: Latif R, MJ Afzal, MI Khan, MS Khan, MA Bashir, S Hussain, M Ehsan (2021). Co-Application of farmyard manure and gypsum improves yield and quality of peanut (Arachis hypogaea) under rainfed conditions. Intl J Agric Biol 26:224-230 
the crop productivity and fertilizer usage. Approximately $50 \%$ of the increased productivity is attributed to the fertilizer use in the last decades (Erisman et al. 2008). Mostly farmers prefer mineral fertilizers over the organic manures to increase crop productivity without considering the soil and environmental health (Abdelhafez et al. 2012). The long-term use of mineral fertilizers can deteriorate soil health resulting in soil acidification, poor soil aggregation, and micronutrients deficiency (Karmakar et al. 2020).

It is a fact that the minimal use of chemical fertilizers and increased use of organic amendments can positively affect the physico-chemical properties of soil, by influencing $\mathrm{pH}$, infiltration rate, and water holding capacity and serving as potential nutrients sources (Mahmoodabadi et al. 2010; Sawrup 2010; Cesarano et al. 2017). Due to a number of benefits, the use of soil organic fertilizers is being widely accepted (Uygur and Karabatak 2009; Urra et al. 2019). Furthermore, the combined use of organic and inorganic fertilizers could be an appropriate and efficient practice for increasing the efficiency of the chemical fertilizer improving the soil health and productivity (Schoebitz and Vidal 2016). Therefore, the present study was conducted with the aim to investigate the effect of coapplication of organic and inorganic fertilizers on yield, quality of peanut and physical properties of soil under rainfed conditions. We hypothesized that the integrated use of FYM and GYP under field conditions may improve the yield, protein, oil contents in peanut as well as moiture contents and reduce the bulk density of soil.

\section{Materials and Methods}

\section{Experimental setup and treatments}

A field experiment was conducted at Barani Agricultural Research Institute, Chakwal ( $\left.32^{\circ} 56^{\prime} 0^{\prime \prime} \mathrm{N}, 72^{\circ} 42^{\prime} 0^{\prime \prime} \mathrm{E}\right)$ to evaluate the effect of organic and inorganic amendments on soil physical properties, peanuts yield and quality under rain-fed conditions (average rainfall $\leq 600 \mathrm{~mm}$ ) during the years 2018 and 2019. Two months prior to sowing, poultry manure (PM) (37.1 $\left.\mathrm{t} \mathrm{ha}^{-1}\right)$, farmyard manure (FYM) (49.4 t ha $\left.{ }^{-1}\right)$, gypsum (GYP) $\left(2.5 \mathrm{t} \mathrm{ha}^{-1}\right)$, liquid humic acid (HA) (49.4 $\left.\mathrm{L} \mathrm{ha}^{-1}\right)$ and GYP $\left(1.2 \mathrm{t} \mathrm{ha}^{-1}\right)+$ FYM $\left(24.7 \mathrm{t} \mathrm{ha}^{-1}\right)$ (in 1:1) were applied in the respective plots $(5 \mathrm{~m} \times 5 \mathrm{~m})$ following randomized complete block design (RCBD) replicated thrice. Peanuts seeds of variety BARI-2011 were sown at the rate of $74 \mathrm{~kg} \mathrm{ha}^{-1}$ using drill during last week of April and crop was harvested in the $1^{\text {st }}$ week of November each year. Plant density was maintained 30 days after sowing, and all other parameters were recorded after 180 days of sowing. Recommended doses of nitrogen $(\mathrm{N})$, phosphorus $(\mathrm{P})$ and potassium $(\mathrm{K})$ were applied at the rate of 20,80 , and $60 \mathrm{~kg}$ $\mathrm{ha}^{-1}$ using di-ammonium phosphate (DAP), single super phosphate (SSP) and sulfate of potash (SOP) prior to sowing during field preparation.

\section{Physico-chemical properties of soil}

Two months prior to sowing during both years, a composite sample of sieved soil $(2 \mathrm{~mm})$ was used to analyze the soil physico-chemical properties and nutrients (i.e., $\mathrm{N}, \mathrm{P}$ and $\mathrm{K}$ ) (Table 1). The soil texture was determined by hydrometer method (Bouyoucos 1951). While to determine soil moisture content $(\%)$, gravimetric method was followed (Reynolds 1970). Soil electrical conductivity (EC) was measured using EC meter (S505141 EC Meter, Sper Scientific, USA) while, $\mathrm{pH}$ by the $\mathrm{pH}$ meter (HI8520 $\mathrm{pH}$ Meter, Hanna Instruments, Italy). The concentrations of $\mathrm{Ca}^{+2}$ and $\mathrm{Mg}^{+2}$ in soils were determined using EDTA method (Estefan et al. 2013). Organic matter content in the soil was determined following Walkley Black method (Walkley and Black 1934). While, contents of $\mathrm{N}, \mathrm{P}$ and $\mathrm{K}$ in the soils were determined via Kjeldhal apparatus (Bremner 1960), spectrophotometer and flame photometer (Stanford and English 1949), respectively, following standard protocols.

In order to evaluate the effect of different organic and inorganic amendments on soil physical properties, bulk density, infiltrations rate, and moisture percentage of soils were determined after harvesting of crop each year. To determine soil bulk density, undisturbed soil cores having 5 $\mathrm{cm}$ internal diameter and with $6 \mathrm{~cm}$ height were drawn from 0-15 cm and 15-30 cm using a core sampler. After collection, samples were oven dried at $105^{\circ} \mathrm{C}$ until constant weight, and bulk density $\left(\mathrm{Mg} \mathrm{m}^{-3}\right)$ was calculated by dividing the weight of oven dried soil samples to the volume of core used (Veihmeyer and Hendrickson 1948). While, ring infiltrometers of large diameter were used to measure infiltration rate (Johnson 1963). To assess moisture percentage, the gravimetric method was followed by weighing fresh and oven dried samples. (Topp and Ferre 2002).

\section{Nutrient analyses of poultry and farm yard manure}

For nutrient analyses of PM and FYM, $0.5 \mathrm{~g}$ sample of each manure was digested with sulfuric acid $\left(\mathrm{H}_{2} \mathrm{SO}_{4}\right)$ and hydrogen peroxide $\left(\mathrm{H}_{2} \mathrm{O}_{2}\right)$ following method described by (Wolf 1982). This digestion mixture was heated till the appearance of clear solution and $\mathrm{N}, \mathrm{P}$ and $\mathrm{K}$ contents were measured using Kjeldahl, spectrophotometer and flame photometer, respectively (Table 2).

\section{Peanut yield and quality attributes}

The plant density was recorded on $30^{\text {th }}$ day of sowing each year. For number of pods plant ${ }^{-1}, 100$-grain weight and pods yield, peanut crop was harvested after $180 \mathrm{~d}$ of sowing both in 2018 and 2019. To determine the effect of amendments on quality of peanut, the crude protein and oil contents were analyzed from the harvested peanut seeds. Peanut seeds were initially dried to a constant weight at $50^{\circ} \mathrm{C}$. After deshelling, seeds were crushed and ground to a fine powder. 
Latif et al. / Intl J Agric Biol, Vol 26, No 2, 2021

Table 1: Physicochemical characteristics of soils used in this study prior to sowing during 2018 and 2019

\begin{tabular}{|c|c|c|}
\hline Parameters & 2018 & 2019 \\
\hline Texture & Sandy clay loam (sand $51.2 \%$ clay $29.8 \%$ and silt $19 \%$ ) & Sandy clay loam (sand $52 \%$ clay $28.5 \%$ and silt $19.5 \%$ ) \\
\hline Moisture (\%) & $8.75 \pm 0.85$ & $10.7 \pm 1.10$ \\
\hline $\mathrm{pH}$ & $7.85 \pm 0.20$ & $7.60 \pm 0.27$ \\
\hline $\mathrm{ECe}\left(\mathrm{dSm}^{-1}\right)$ & $1.85 \pm 0.07$ & $1.91 \pm 0.08$ \\
\hline $\mathrm{CEC}\left(\mathrm{cmol}_{\mathrm{c}} \mathrm{kg}^{-1}\right)$ & $8.60 \pm 1.05$ & $11.1 \pm 1.70$ \\
\hline Soluble $\mathrm{Ca}^{2+}+\mathrm{Mg}^{2+}\left(\mathrm{mmol}_{\mathrm{c}} \mathrm{L}^{-1}\right)$ & $7.15 \pm 0.60$ & $7.80 \pm 0.65$ \\
\hline Organic matter $(\%)$ & $0.50 \pm 0.03$ & $0.57 \pm 0.03$ \\
\hline $\mathrm{CaCO}_{3}(\%)$ & $4.60 \pm 0.19$ & $4.90 \pm 0.16$ \\
\hline Total nitrogen $(\%)$ & $0.47 \pm 0.02$ & $0.54 \pm 0.01$ \\
\hline Available phosphorus $\left(\mathrm{mg} \mathrm{kg}^{-1}\right)$ & $4.58 \pm 0.10$ & $5.66 \pm 0.15$ \\
\hline Available potassium $\left(\mathrm{mg} \mathrm{kg}^{-1}\right)$ & $130 \pm 14.9$ & $141 \pm 15.5$ \\
\hline Bulk density $\left(\mathrm{Mg} \mathrm{m}^{-3}\right)(0-15 \mathrm{~cm})$ & $1.42 \pm 0.02$ & $1.41 \pm 0.02$ \\
\hline Bulk density $\left(\mathrm{Mg} \mathrm{m}^{-3}\right)(15-30 \mathrm{~cm})$ & $1.45 \pm 0.03$ & $1.43 \pm 0.03$ \\
\hline Infiltration rate $\left(\mathrm{mm} \mathrm{h}^{-1}\right)$ & $19.3 \pm 1.75$ & $18.7 \pm 1.30$ \\
\hline
\end{tabular}

$\mathrm{ECe}=$ Electrical conductivity; $\mathrm{CEC}=$ Cation exchange capacity; $\mathrm{CaCO}_{3}=$ Calcium carbonate

Values represent means $(n=3) \pm$ standard errors

Table 2: Nutrients in poultry and farm yard manures used during 2018 and 2019

\begin{tabular}{|c|c|c|c|c|}
\hline \multirow[t]{2}{*}{ Parameters } & \multicolumn{2}{|c|}{2018} & \multicolumn{2}{|c|}{2019} \\
\hline & $\mathrm{PM}$ & FYM & $\mathrm{PM}$ & FYM \\
\hline Nitrogen (\%) & $2.80 \pm 0.13$ & $0.53 \pm 0.06$ & $2.75 \pm 0.11$ & $0.51 \pm 0.05$ \\
\hline Phosphorus (\%) & $1.40 \pm 0.08$ & $0.21 \pm 0.02$ & $1.42 \pm 0.09$ & $0.23 \pm 0.03$ \\
\hline
\end{tabular}

$\mathrm{PM}=$ Poultry manure; FYM = Farm yard manure

Values represent means $(\mathrm{n}=3) \pm$ standard errors

To measure crude protein content, total $\mathrm{N}$ content was determined using a digestion and distillation system following micro-Kjeldahl method (Sweeney and Rexroad 1987), and then crude protein content was calculated by multiplying $\mathrm{N}$ content by a factor of 6.25 (Jones 1931). While, for the oil content, Soxhlet apparatus (Soxtec 2050, FOSS, Denmark) was used (Niu et al. 2014).

\section{Statistical analysis}

The analysis of variance was used to estimate variations from mean $(n=3)$ values by standard errors. Means were compared at 5\% level of significance by applying LSD test using Statistix 8.1 (Snedecor and Cochran 1980).

\section{Results}

\section{Effects on yield attributes}

The results showed that organic and inorganic amendments did not reveal great differences in plant density among the applied treatments; however, the combined application of GYP and FYM significantly improved the plant density by $18 \%$ than control, while, $13 \%$ higher plant density was observed by the individual application of HA as compared to control (Fig. 1a).

The application of organic and inorganic fertilizers had a positive influence on the number of pods of peanut as compared to control during both years 2018 and 2019 (Fig. 1b). Approximately, 9.6, 29, 17 and 9.8\% more number of pods per plant were observed with application of PM, FYM, GYP, and HA, respectively than control treatment (Fig. 1b).
The combined application of GYP and FYM had 57\% higher number of pods than control.

Application of PM, FYM, GYP, and HA had 16, 17, 13 and $14 \%$ higher 100-grain weight, than control treatment respectively (Fig. 1c). The combined use of GYP and FYM increased 25\% 100-grain weight as compared to control treatment (Fig. 1c). For pods yield, 37, 42, 27 and 17\% higher yield values of peanut were observed on applying PM, FYM, GYP, and HA, than control respectively (Fig. 1d). While on combined application of GYP and FYM, there was an increase of $67 \%$ in peanut yield than control. Briefly, the application of organic and inorganic fertilizers had significantly $(P \leq 0.05)$ improved the yield of peanut as compared to control.

\section{Effects on quality attributes}

The co-application of organic and inorganic fertilizers significantly $(P \leq 0.05)$ affected the crude protein and oil content of peanut as compared to control during both years (Fig. 2a and b). Results showed that 13, 7.8, 6.7 and 12\% higher crude protein contents were observed with PM, FYM, GYP, and HA, than control respectively (Fig. 2a). The combined application of GYP and FYM had $22 \%$ higher crude protein content than control. Similarly, 3.6, 2.7, 2.4 and $4.5 \%$ higher oil contents were observed on applying PM, FYM, GYP, and HA, than control respectively (Fig. 2b). Using GYP in combination with FYM had $8.5 \%$ higher oil contents than control.

\section{Effects on soil properties}

Co-application of organic and inorganic fertilizers improved 

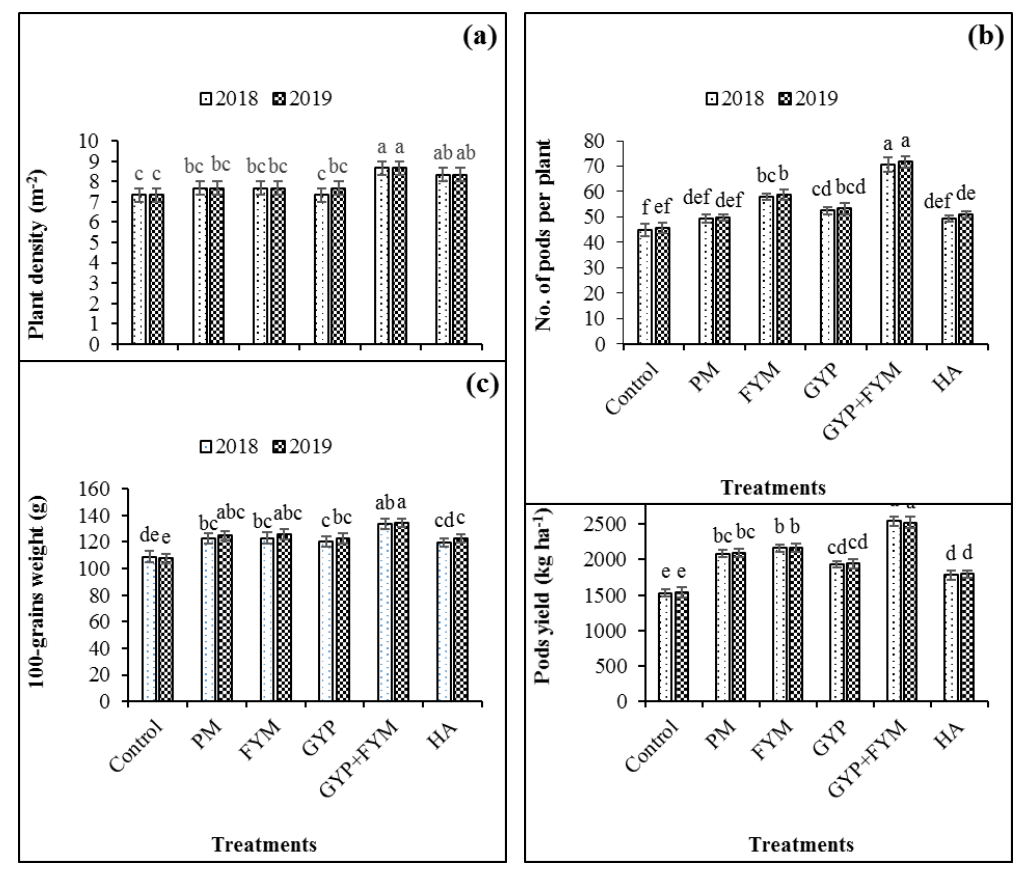

Fig. 1: Effects of organic and inorganic amendments on plants density (a), no. of pods per plant (b), 100-grains weight (c) and pods yield (d) of peanut grown during 2018 and 2019. Plant density was noticed after $30 \mathrm{~d}$ of sowing, and all other values shown here were taken after $180 \mathrm{~d}$ of sowing. Columns and bars represent means and standard errors, respectively of triplicate values. Means having different letters differ significantly according to LSD test at $P \leq 0.05$. (Control, treatment without any amendments; $P M$, treatment with only poultry manure; $F Y M$, treatment with only farm yard manure; $G Y P$, treatment with only gypsum; $G Y P+F Y M$, treatment with both gypsum and farm yard manure; $H A$, treatment with only liquid humic acid)
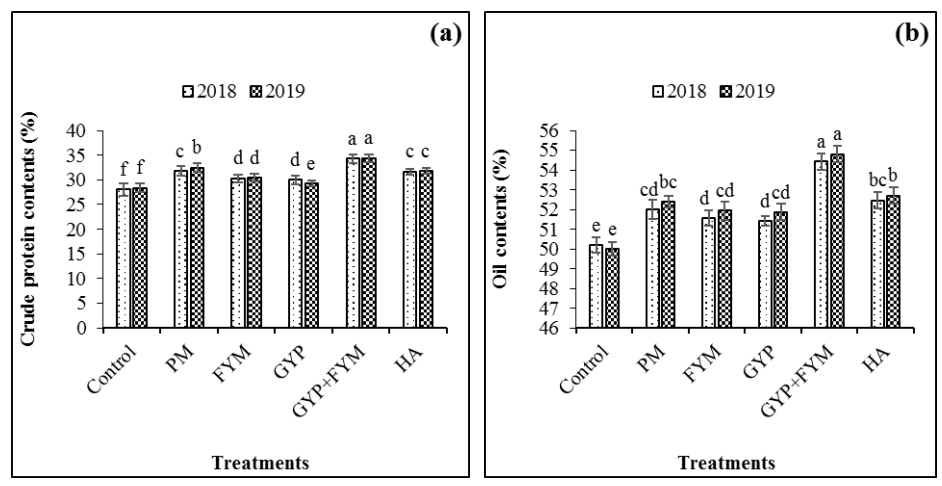

Fig. 2: Effect of organic and inorganic amendments on crude protein contents (a) and oil contents (b) of peanut grown during 2018 and 2019. All the values shown here were taken after $180 \mathrm{~d}$ of sowing. Columns and bars represent means and standard errors, respectively of triplicate values. Means having different letters differ significantly according to LSD test at $P \leq 0.05$

soil physical properties including soil bulk density, infiltration rate and moisture percentage (Table 3). Approximately 4.7, 4.8, 3.8 and $4.3 \%$ reduced bulk density $(0-15 \mathrm{~cm})$ than control was observed by the application of PM, FYM, GYP, and HA, respectively (Table 3). While, $8.7 \%$ reduced bulk density was observed on combined application of GYP and FYM. Almost similar trend was observed for the bulk density of the subsoil $(15-30 \mathrm{~cm})$. On the other hand, 8.9, 8.3, 7.9 and $1.9 \%$ reduced rate of water infiltration was observed on applying PM, FYM, GYP and HA, as compared to control respectively (Table 3). While on integrated use of GYP and FYM, 10\% decreased water infiltration rate was observed as compared to control. In case of moisture content, 55, 48, 43 and 17\% increased moisture content as compared to control was observed by the application of PM, FYM, GYP, and HA, respectively (Table 3), while combined application of GYP and FYM, increased $88 \%$ moisture content as compared to control was observed. Briefly, addition of each organic or inorganic amendment improved the soil physical properties but the effect of coapplication of GYP and FYM was most significant. 
Latif et al. / Intl J Agric Biol, Vol 26, No 2, 2021

Table 3: Effects of organic and inorganic amendments on soil physical properties during 2018 and 2019

\begin{tabular}{|c|c|c|c|c|c|c|c|c|}
\hline \multirow[t]{3}{*}{ Treatments } & \multicolumn{4}{|c|}{ Bulk density $\left(\mathrm{Mg} \mathrm{m}^{-3}\right)$} & \multicolumn{2}{|c|}{ Infiltration rate $\left(\mathrm{mm} \mathrm{h}^{-1}\right)$} & \multicolumn{2}{|c|}{ Moisture percentage (\%) } \\
\hline & \multicolumn{2}{|c|}{2018} & \multicolumn{2}{|c|}{2019} & \multirow{2}{*}{2018} & \multirow{2}{*}{2019} & \multirow{2}{*}{2018} & \multirow{2}{*}{2019} \\
\hline & $(0-15 \mathrm{~cm})$ & $(15-30 \mathrm{~cm})$ & $(0-15 \mathrm{~cm})$ & $(15-30 \mathrm{~cm})$ & & & & \\
\hline Control & $1.41 \pm 0.01^{\mathrm{a}}$ & $1.45 \pm 0.01^{\mathrm{a}}$ & $1.40 \pm 0.01^{\mathrm{a}}$ & $1.44 \pm 0.01^{\mathrm{a}}$ & $18.67 \pm 1.16^{\mathrm{a}}$ & $18.07 \pm 1.21^{\mathrm{bc}}$ & $5.20 \pm 0.20^{\mathrm{d}}$ & $4.20 \pm 0.16^{\mathrm{e}}$ \\
\hline PM & $1.35 \pm 0.01^{\mathrm{bc}}$ & $1.38 \pm 0.01^{\mathrm{bcd}}$ & $1.33 \pm 0.02^{\mathrm{cd}}$ & $1.37 \pm 0.01^{\mathrm{cd}}$ & $17.00 \pm 0.98^{\mathrm{de}}$ & $17.00 \pm 1.15^{\mathrm{de}}$ & $6.50 \pm 0.24^{\mathrm{b}}$ & $6.81 \pm 0.33^{\mathrm{b}}$ \\
\hline FYM & $1.35 \pm 0.01^{\mathrm{bc}}$ & $1.38 \pm 0.01^{\mathrm{bcd}}$ & $1.32 \pm 0.01^{\mathrm{de}}$ & $1.36 \pm 0.02^{\mathrm{de}}$ & $17.12 \pm 1.17^{\mathrm{de}}$ & $16.93 \pm 1.18^{\mathrm{de}}$ & $6.20 \pm 0.16^{\mathrm{bc}}$ & $6.50 \pm 0.33^{\mathrm{b}}$ \\
\hline GYP & $1.36 \pm 0.01^{\mathrm{b}}$ & $1.39 \pm 0.01^{\mathrm{bc}}$ & $1.35 \pm 0.02^{\mathrm{bc}}$ & $1.37 \pm 0.01^{\mathrm{d}}$ & $17.20 \pm 1.15^{\mathrm{d}}$ & $17.00 \pm 1.16^{\mathrm{de}}$ & $6.10 \pm 0.24^{\mathrm{bc}}$ & $6.52 \pm 0.41^{\mathrm{bc}}$ \\
\hline GYP+FYM & $1.29 \pm 0.01^{\mathrm{ef}}$ & $1.34 \pm 0.01^{\mathrm{e}}$ & $1.26 \pm 0.01^{\mathrm{f}}$ & $1.31 \pm 0.01^{\mathrm{f}}$ & $16.73 \pm 1.27^{\mathrm{ef}}$ & $16.47 \pm 1.13^{\mathrm{f}}$ & $7.91 \pm 0.33^{\mathrm{a}}$ & $8.20 \pm 0.24^{\mathrm{a}}$ \\
\hline HA & $1.36 \pm 0.01^{\mathrm{bc}}$ & $140 \pm 0.01^{\mathrm{b}}$ & $1.34 \pm 0.01^{\mathrm{bcd}}$ & $1.38 \pm 0.01^{\text {bcd }}$ & $18.30 \pm 1.46^{\mathrm{ab}}$ & $17.87 \pm 1.39^{\mathrm{c}}$ & $4.90 \pm 0.24^{\mathrm{d}}$ & $5.20 \pm 0.16^{\mathrm{cd}}$ \\
\hline
\end{tabular}

\section{Discussion}

In this study, improved plant density and yield attributes of peanut were observed on the addition of organic and inorganic amendments. Taufiq et al. (2016) found improved growth, plants density and yield of peanut on application of GYP and manures. Kausar et al. (2020) reported a significant increase in wheat (Triticum aestivum L.) yield by the addition of GYP and green manures. Improved yield and growth traits in maize (Zea mays L.) by the addition of PM and HA might be due to the addition of organic matter by these amendments, thus improving the physical, chemical, and biological properties of soil, and increasing nutrients availability within the rhizosphere zone, which consequently enhanced overall growth and yield attributes of peanut (Rizk et al. 2012; Zhao et al. 2016; Hussain et al. 2018). Other possible explanations for the improved yield on applying amendments could be the enhanced soil moisture retention, which is directly linked with nutrients mobility and availability as found in present study with increased moisture percentage and nutrient content found in treatment where GYP and FYM applied in combination (Parihar et al. 2019; Mariotte et al. 2020).

The improved crude protein and oil contents in mustard (Brassica juncea L.) by the application of HA and manure were previously reported by Dubey et al. (2019). The improved effect on quality of peanut could be due to the increased nutrients uptake particularly of $\mathrm{N}$, and better translocation of assimilates (Ravikumar et al. 2019). Combined application of GYP and FYM proved most effective in improving crude protein and oil contents significantly, and this promoting effect can be attributed to the ability of FYM and especially GYP to add sulfur (S) within the soil and as sulfur have major role in synthesis of protein and oil in oilseed plants (Caires et al. 2006; Rocha et al. 2017; Raza et al. 2018; Ariraman and Kalaichelvi 2020; Chahal et al. 2020).

The integrated use of different organic and inorganic amendments could significantly improve soil properties (Ahmad et al. 2013). In our study, reduced soil bulk density, water infiltration rate and improved moisture contents on application of organic and inorganic amendments were observed. This promotive effect could be due to the fact that organic amendments together with inorganic fertilizers improve organic matter contents, soil aggregation, roots growth and consequently increase the total volume of biopores in the amended plots (Bandyopadhyay et al. 2010; Singh and Benbi 2016; Bekele et al. 2020) in addition to providing essential nutrients to increase the soil fertility and productivity (Rasoulzadeh and Yaghoubi 2010; Agbede et al. 2017). Reduced bulk density on addition of amendments could be due to the increase in overall volume of pore spaces due to organic matter addition (He et al. 2020), while the binding/water holding characteristic of the amendments could be the reason of the reduced infiltration rate and increased moisture content (Hudson 1994; Verheijen et al. 2010; Aytenew and Bore 2020).

\section{Conclusion}

All the tested organic and inorganic amendments in our field trial showed improved effects on yield, quality of peanut and soil physical properties. While, co-application of GYP and FYM was found to the most effective in improving yield attributes (100 grain weight, no. of pods per plant and pods yield), quality attributes (crude protein and oil content) of peanut, and soil physical properties (bulk density, infiltration rate and moisture percentage). Furthermore, our findings suggest that co-application of GYP and FYM under rain-fed conditions could serve as a better alternate to the excessive usage of single source chemical fertilizers in order to achieve the ultimate goals of sustainable food production having improved yield, quality and soil physical health.

\section{Acknowledgements}

Authors are thankful to the staff of Barani Agricultural Research Institute (BARI), Chakwal, Pakistan for their support in providing space in the form of field plots for the experiment and the laboratory technicians of Soil and Water Testing Laboratory Chakwal, Pakistan for their assistance in samples analyses.

\section{Author Contributions}

RL and ME conceptualized the study, conducted the experiment, managed the resources and analyzed the data, MJA, MIK and MSK conducted the statistical analysis, MJA, MIK and MSK wrote original draft of the manuscript, RL supervised the study and all processes. MAB visualized 
the experiment conceptually, SH contributed in editing the manuscript. MIK corresponded to the journal for submission and review. All authors have read and agreed to the submitted version of the manuscript.

\section{Conflict of Interest}

Authors declare no conflict of interest.

\section{Data Availability}

We hereby declare that data related to this article, are available with the corresponding author and will be produced on demand.

\section{Ethics Approval}

Ethical approval is not applicable in this study.

\section{Funding Source}

This study was partially funded by the Higher Education Commission (HEC) of Pakistan (project number NRPU7730).

\section{References}

Abdelhafez AA, HH Abbas, RS Abd-El-Aal, NF Kandil, J Li, W Mahmoud (2012). Environmental and health impacts of successive mineral fertilization in Egypt. Clean Soil Air Water 40:356-363

Agbede TM, AO Adekiya, EK Eifediyi (2017). Impact of poultry manure and NPK fertilizer on soil physical properties and growth and yield of carrot. J Hortic Res 25:81-88

Ahmad W, Z Shah, F Khan, S Ali, W Malik (2013). Maize yield and soil properties as influenced by integrated use of organic, inorganic and bio-fertilizers in a low fertility soil. Soil Environ 32:121-129

Ariraman R, K Kalaichelvi (2020). Effect of Sulphur nutrition in Groundnut: A review. Agric Rev 41:132-138

Ashfaq A, M Ashraf, MIA Kokhar (2003). Integrated land and water resources management in Pothwar: Issues and options. Sci Intl 15:8792

Aytenew M, G Bore (2020). Effects of organic amendments on soil fertility and environmental quality: A review. J Plant Sci 8:112-119

Bandyopadhyay PK, S Saha, PK Mani, B Mandal (2010). Effect of organic inputs on aggregate associated organic carbon concentration under long-term rice-wheat cropping system. Geoderma 154:379-386

Bekele T, L Wogi, S Tamiru (2020). Effect of gypsum and farmyard manure on selected physicochemical properties of saline sodic soil at Amibara, Ethiopia. Intl J Novel Res Life Sci 7:15-26

Bouyoucos GJ (1951). A recalibration of the hydrometer method for making mechanical analysis of soils. Agron J 43:434-438

Bremner JM (1960). Determination of nitrogen in soil by the Kjeldahl method. J Agric Sci 55:11-33

Busscher WJ, JM Novak, DE Evans, DW Watts, M Niandou, M Ahmedna (2010). Influence of pecan biochar on physical properties of a Norfolk loamy sand. Soil Sci 175:10-14

Caires EF, S Churka, FJ Garbuio, RA Ferrari, MA Morgano (2006). Soybean yield and quality a function of lime and gypsum applications. Sci Agric 63:370-379

Cesarano G, FD Filippis, AL Storia, F Scala, G Bonanomi (2017). Organic amendment type and application frequency affect crop yields, soil fertility and microbiome composition. Appl Soil Ecol 120:254-264

Chahal HS, A Sing, GS Malhi (2020). Role of Sulphur nutrition in oilseed crop production-A review. J Oilseed Brassica 11:95-102
Dubey RK, PK Dubey, PC Abhilash (2019). Sustainable soil amendments for improving the soil quality, yield and nutrient content of Brassica juncea (L.) grown in different agroecological zones of eastern Uttar Pradesh, India. Soil Till Res 195:104418

El-Akhal MR, A Rincón, T CobaDL Peña, MM Lucas, N El-Mourabit, S Barrijal, JJ Pueyo (2013). Effects of salt stress and rhizobial inoculation on growth and nitrogen fixation of three peanut cultivars. Plant Biol 15:415-421

Erisman JW, MA Sutton, J Galloway, Z Klimont, W Winiwarter (2008). How a century of ammonia synthesis changed the world. Nat Geosci 1:636-639

Esmaeilian Y, AR Sirousmehr, MR Asghripour, E Amiri (2012). Comparison of sole and combined nutrient application on yield and biochemical composition of sunflower under water stress. Intl J Appl Sci Technol 2:214-220

Estefan G, R Sommer, R Ryan (2013). Methods of Soil, Plant, and Water Analysis: A manual for the West Asia and North Africa Region, $3^{\text {rd }}$ Edition, pp:170-176. International Center for Agriculturl Research in Dry Areas (ICARDA)

He L, J Zhao, S Yang, H Zhou, S Wang, X Zhao, G Xing (2020). Successive biochar amendment improves soil productivity and aggregate microstructure of a red soil in a five-year wheat-millet rotation pot trial. Geoderma 376; Article 114570

Hudson BD (1994). Soil organic matter and available water capacity. J Soil Water Conserv 49:189-194

Hussain A, AM Subhanullah, W Ali, M Tariq, S Muhammad, MK Khalil, MO Khan (2018). Impression of disparate levels of poultry manure and humic acid on the yield and yield traits of maize (Zea mays L.). Eur J Exp Biol 8; Article 23

Hussainy SAH, S Arivukodi (2019). Effect of irrigation regimes on the growth, yield and water use efficiency under groundnut based intercropping system: A review. Intl. J Chem Stud 7:691-698

Johnson AI (1963). A field method for measurement of infiltration. US Government Printing Office, Washington DC, USA

Jones DB (1931). Factors for converting percentages of nitrogen in foods and feeds into percentages of protein, Vol. 183, pp:1-21. United States Department of Agriculture, Washington DC, USA

Karmakar S, A Bhattacharyya, B Ghosh, R Roy, S Kumar, B Kar, G Saha (2020). Suitability of coupling application of organic and inorganic fertilizers for crop cultivation. In: Ecological and Practical Applications for Sustainable Agriculture, pp:14-177. Bauddh K, S Kumar, RP Singh, J Korstad (Eds). Springer, Singapore

Kausar R, MI Akram, MI Choudhary, A Malik, AR Zahid, B Ali (2020) Soil moisture retention and rainfed wheat yield variations by the addition of gypsum and green manure. $J$ Soil Sci Environ Manage 11:6-16

Kephe PN, KK Ayisi, BM Petja, AP Mulaudzi, KE Mabitsela (2020). Factors influencing the production of oilseed crops among smallholder farmers in Limpopo Province. Oilseeds Fats Crops Lipids 27:41-49

Kiniry JR, CE Simpson, AM Schubert, JD Reed (2005). Peanut leaf area index, light interception, radiation use efficiency, and harvest index at three sites in Texas. Field Crops Res 91:297-306

Kumar V, RK Naresh, S Kumar, S Kumar, A Kumar, RK Gupta, NC Mahajan (2018). Efficient nutrient management practices for sustaining soil health and improving rice-wheat productivity: A review. J Pharmacogn Phytochem 7:585-597

Mahmoodabadi M, RS Amini, K Khazaeepour (2010). Middle-east $J$ Sci Res 5:214-217

Mahrous NM, SS Safina, HH Abo-Taleb, SM El-Sayed El-Behlak (2015). Integrated use of organic, inorganic and bio fertilizers on yield and quality of two peanut (Arachis hypogaea L.) cultivars grown in a sandy saline soil. Amer-Euras J Agric Environ Sci 15:1067-1074

Mariotte P, T Cresswell, MP Johansen, JJ Harrison, C Keitel, FA Dijkstra (2020). Plant uptake of nitrogen and phosphorus among grassland species affected by drought along a soil available phosphorus gradient. Plant Soil 448:1-12

Meena HN, M Meena, RS Yadav (2016). Comparative performance of seed types on yield potential of peanut (Arachis hypogaea L.) under saline irrigation. Field Crops Res 196:305-310 
Niu L, J Li, MS Chen, ZF Xu (2014). Determination of oil contents in Sacha inchi (Plukenetia volubilis) seeds at different developmental stages by two methods: Soxhlet extraction and time-domain nuclear magnetic resonance. Ind Crops Prod 56:187-190

Parihar M, VS Meena, PK Mishra, A Rakshit, M Choudhary, RP Yadav, JK Bisht (2019). Arbuscular mycorrhiza: a viable strategy for soil nutrient loss reduction. Arch Microbiol 201:723-735

Rasoulzadeh A, A Yaghoubi (2010). Effect of cattle manure on soil physical properties on a sandy clay loam soil in North-West Iran. J Food Agric Environ 8:976-979

Ravikumar C, M Ganapathy, D Ganesamoorthy, A Karthikeyan, M Saravanaperumal, G Murugan (2019). Effect of Inm on growth, yield and quality parameters of irrigated groundnut (Arachis hypoagea L.) Var. Vri-2 for sandy loam soils. Plant Arch 19:745-749

Raza MA, LY Feng, A Manaf, A Wasaya, M Ansar, A Hussain, JX Chen (2018). Sulphur application increases seed yield and oil content in sesame seeds under rainfed conditions. Field Crops Res 218:51-58

Reynolds SG (1970). The gravimetric method of soil moisture determination Part III An examination of factors influencing soil moisture variability. J Hydrol 11:288-300

Rizk TY, EM Soliman, FE El-Araby, HA El-Sayed (2012). Enhancement of groundnut productivity by inoculation with Bradyrhizobium and Rizobacteria under different levels of compost in sandy soils. Egypt J Agron 34:267-81

Rocha ITM, NS Bezerra, FJ Freire, ERD Souza, MBGDS Freire, ECAD Oliveira, DES Neto (2017). Aluminum buffering in acid soil under mineral gypsum application. Afr J Agric Res 12:597-605

Sarkar D, VS Meena, A Haldar, A Rakshit (2017). Site-specific nutrient management (SSNM): A unique approach towards maintaining soil health. In: Adaptive Soil Management: From Theory to Practices, pp:69-88. Rakshit A, PC Abhilash, HB Singh, S Ghosh (Eds). Springer, Singapore

Sawrup A (2010). Integrated plant nutrient supply and management strategies for enhancing soil fertility, input use efficiency and crop productivity. J Ind Soc Soil Sci 58:25-30

Schoebitz M, G Vidal (2016). Microbial consortium and pig slurry to improve chemical properties of degraded soil and nutrient plant uptake. J Soil Sci Plant Nutr 16:226-236

Shad M, AP Humayun, N Haq, K Hyder, AU Muhammad (2009). Evaluation of biochemical and phytochemical composition of some groundnut varieties grown in arid zone of Pakistan. Pak J Bot 41:2739-2749
Singh P, DK Benbi (2016). Effect of inorganic fertilizers and farm yard manure on physical properties of soil under rice-wheat cropping. Agric Res J 53:328-333

Snedecor GW, WG Cochran (1980). Statistical methods 1989. Iowa State College Press, Ames, Iowa, USA

Stanford G, L English (1949). Use of the flame photometer in rapid soil tests for K and Ca. Agron J 41:446-447

Sweeney RA, PR Rexroad (1987). Comparison of LECO FP-228 nitrogen determinator with AOAC copper catalyst Kjeldahl method for crude protein. J Assoc Offic Anal Chem 70:1028-1030

Taufiq A, A Wijanarko, A Kristiono (2016). Effect of amelioration on growth and yield of two groundnut varieties on saline soil. J Degr Min Lands Manage 3:639-647

Topp GC, PA Ferre (2002). The soil solution phase. Methods of soil analysis: Part 4. Wiley

Urra J, I Alkorta, C Garbisu (2019). Potential benefits and risks for soil health derived from the use of organic amendments in agriculture. Agronomy 9; Article 542

Uygur V, I Karabatak (2009). The effect of organic amendments on mineral phosphate fractions in calcareous soils. J Plant Nutr Soil Sci 172:336-345

Veihmeyer FJ, AH Hendrickson (1948). Soil density and root penetration. Soil Sci 65:487-494

Verheijen F, S Jeffery, AC Bastos, MVD Velde, I Diafas (2010). Biochar application to soils. A critical scientific review of effects on soil properties, processes, and functions. In: JRC Scientific and Technical Reports, pp:1-166. European Commission, Publisher, Luxembourg

Walkley A, IA Black (1934). An examination of the Degtjareff method for determining soil organic matter, and a proposed modification of the chromic acid titration method. Soil Sci 37:29-38

Wang ML, P Raymer, M Chinnan, RN Pittman (2012). Screening of the USDA peanut germplasm for oil content and fatty acid composition. Biomass Bioener 39:336-343

Wolf B (1982). A comprehensive system of leaf analyses and its use for diagnosing crop nutrient status. Commun Soil Sci Plant Anal 13:1035-1059

Zhao YN, XH He, XC Huang, YQ Zhang, XJ Shi (2016). Increasing soil organic matter enhances inherent soil productivity while offsetting fertilization effect under a rice cropping system. Sustainability 8; Article 879 